\title{
Environmental Degradation and the Emergence of Agricultural Frontiers in the North West of Cameroon
}

\author{
Humphrey Ngala Ndi ${ }^{1} \&$ Amawa Sani Gur ${ }^{1}$ \\ ${ }^{1}$ Faculty of Social and Management Sciences, Department of Geography, University of Buea, Buea, Cameroon \\ Correspondence: Humphrey Ngala Ndi, P.O. Box 63 Buea, Cameroon. Tel: 237-7788-5649. E-mail: \\ hngalan117@gmail.com
}

Received: March 10, 2014 Accepted: March 31, 2014 Online Published: September 23, 2014

doi:10.5539/jsd.v7n5p111 URL: http://dx.doi.org/10.5539/jsd.v7n5p111

\begin{abstract}
Over the past 50 years, man has changed natural ecosystems more rapidly and profoundly than in any comparable period in history. In the developing countries, these changes have degraded livelihoods, provoking different responses from affected populations, the most common being out-migration. The study examines the environmental degradation on the Mbum sector of the Nkambe plateau, North West region of Cameroon, and the out-migration resulting from it. This is crucial in understanding the anthropogenic threats to farming in an area where agriculture is still rudimentary and crop yields turn to be very sensitive to environmental changes. The nature of environmental degradation and resultant migration were ascertained by analysing data acquired through suitable field and laboratory methods and techniques. Theses analysis revealed that soil impoverishments resulting from inappropriate land uses is the main environmental change on the plateau. The paper recommends the adoption of strong land use policies as a precursor to the modernisation of the farming system to reduce land colonisation, reduce out-migration and stabilise environmental conditions for sustainable agriculture.
\end{abstract}

Keywords: environmental degradation, Nkambe plateau, Mbum plateau, Mbaw plain, movement, degradation

\section{Introduction}

Sarukhan., Whyte and the MA Board of Review Editors (2005) in the Millennium Ecosystem Assessment Report provide one of the strongest evidences so far of the impact of our actions on the natural world. It shows, for example, that over the past 50 years, man has changed natural ecosystems more rapidly, profoundly and extensively than in any comparable period in history. This has brought about substantial net gains in human well-being and economic development. However, not all people, or regions have reaped these benefits fairly. According to the Inclusive Wealth Report 2012 (UNU, IHDP and UNEP, 2012), approximately 60 per cent of the world's natural capital is either being degraded or being unsustainably used, and total factor productivity growth has been driven into the negative range because ecosystem services are an un-priced factor of production causing people not to use them with the discipline of priced factors.

In the developing countries especially those emerging like China, India and Brazil; economic growth is increasing at the detriment of natural factors of production. Malthusian and Neo-Malthusian fears that the rate of population growth and natural resource consumption far outwears the ability of the planet to sustain life again for long are revived by the evidence of the current pressures and alterations exerted by human activities on the earth especially through the rapid industrialisation of the $20^{\text {th }}$ century. Initially the preserve of the more economically developed countries, industrial development has become a global phenomenon albeit at different scales and magnitudes. Schubert et al., (2008), see the recent buoyancy of emerging developing countries as a major factor in the emission of green house gases, while the cornucopians or opponents of Malthus view man-environment relationships within the framework of human perfectibility with the view that only the failure of human ingenuity in his environment can spell doom for him (Rogers., Jalal., \& Boyd, (2008). Despite nuance views on the man-environment nexus, nearly all theorists believe that the planet is delicate and must be cared for if man must continue to benefit from its services. In noting that Africa has the fastest economic growth in the world today, the World Bank explains such growth in terms of increased exploitation of natural resources, agricultural production, services coupled with strong internal demand. Africa's economy is projected to grow by 5.3 per cent in 2014 (World Bank, 2013). Much of such growth only occurs at the expense of ecosystems. In the Millennium Ecosystem Assessment of 2005 commissioned by the United Nations, and conducted by hundreds of scientists 
globally, 15 of the 24 ecosystems examined were seen to be either suffering from degradation, or being unsustainably used (Sarukhan., Whyte., and the MA Board of Review Editors, 2005).

In recent years, arable lands in the tropics have suffered from an unprecedented rate of environmental degradation. In the definition of the UN Convention to combat desertification, land degradation refers to the reduction or loss of biological or economic productivity of ecosystems resulting from climatic variations, land uses and a combination of processes such as soil erosion, soil impoverishment and a sustained loss of vegetation cover (UNCCD, 1994). The UNU-EHS, UNHCR, CIESIN, CARE, \& the Social Dimensions of Climate Change Programme (2009) and Oliver Smith \& Xiaomeng (2009) observe that the destruction of livelihoods dependent on ecosystems is likely to be a major long term driver of migration and that environmental change induced migration is not a new phenomenon in human history. In Bangladesh, sea level rise by over $12 \mathrm{~cm}$ since 2000 have caused the Bay of Bengal to lose residential and arable land, thereby pushing away over 3million people to urban slums and other countries (Schubert, 2008). Similarly, Graßi, et al. (2004), and Voller \& Fischer (2009), and the International Organisation for Migration (IOM) attribute rural-urban and cross-border migrations to land degradation, decline in freshwater, soils impoverishment and desertification. Ngane E.B, Ngane B.K, Ndjib, Awah \& Ehabe (2012) have also illustrated the increasing intensity of soil degradation by selected land uses in the humid tropical north west region of Cameroon.

Migration, an important component in the man-environment nexus constitutes a coping strategy for populations living in areas of highly degraded arable land. Research in migration has evolved and emerged from the shadows of population studies to occupy centre stage in contemporary area or regional studies, viewing the process as a human adaptation to economic woes which have befallen him in time and place in his life cycle. Circular migration which refers to short-term or seasonal movements between the home and the farm is a traditional coping strategy in West and Central Africa as it represents a livelihood diversifying mechanism (Care et al., 2009). Boncour (2008) corroborates this view point by acknowledging that many consider migration predominantly as a worst-case scenario, associated with crisis and generally as a last resort on which people fall when all else has failed. Human mobility and its links with environmental dynamics like climate change, and hydro-geomorphologic modifications are still not included in the United Nations Framework Convention on Climate Change (UNFCCC) process (UN, 1992). It is neither to be found in the Kyoto Protocol nor in the Bali Road Map. This is even more surprising when we consider that as early as 1990, in its very first assessment report; the Intergovernmental Panel on Climate Change (IPCC) estimated that the greatest single impact of climate change might be on human mobility (Boncour, 2008, and the IOM, 2009).

Migration has received wide attention from geographers because of the spatial component involved in defining it. It has been defined as a permanent or semi-permanent change of residence of an individual or group of people (Johnston, Gregory \& Smith, 1994; Gregory et al., 2009; Week, 2008 \& Newbold, 2010). Migration is often induced by economic, social and environmental motives. Movement motivated by an environmental stressor has been called environmental migration. Like Schubert et al. 2008 and Renaud, Bogardi, Dun, \& Warner, 2007, this study considers the term environmental migrant to refer to any person or group of people that migrate because environmental changes either have such an unfavourable effect on living conditions that previously achieved income levels and standards of living can no longer be attained or the structures necessary for the maintenance of these levels have been destroyed. This concept has been the subject of much debate recently. Renaud, Bogardi, Dun, \& Warner, 2007, have summarised the controversies in the literature into two questions: which category of people can be classified as environmental migrants, and do any people truly fit the definition of environmental migrants? The concept of environmental migration is discredited on the grounds that environmental stressors do not always lead to migration. Whether a move is made or not depends on the degree of resiliency of the person or group of people in question, and rather than standing alone as a concept separate from migration, environmental degradation that causes people to move should be considered as an immediate push factors for migration, amongst many existing background factors which may be social, economic and political. With or without unanimity on the concept of environmental migration, the fact that global warming leading to a rise in sea level will threaten the livelihoods of millions of people especially on small islands thereby displacing them cannot be disputed.

\subsection{Statement of Research Problem}

Although aboriginal populations are rare on earth because people have been known to be incessant movers, the waves of movements today undoubtedly supersede any others in recorded history in scale and frequency. Given the fact that most of our so called renewable resources including the soil have been so profoundly degraded that no possibility of renewals are foreseeable in a reasonable length of man's life, severe environmental threats are prowling around man and his civilisation. 
This paper sets out to establish the nature and causes of environmental change on the Mbum sector of the Nkambe plateau and the resultant local migrations in responses to such changes. The information resulting from such a study is important to understand local environmental dynamics because many global environmental problems can in fact be mitigated by an aggregation of local responses. The Machakos in Kenya is a good example of a local response which has resulted to the reversal of land misuse permitting this territory to continue to support far more people than the doomsters had predicted for it over 75 years ago (Malakoff, 2011). The study therefore shall attempt the following questions: What is the nature of environmental degradation on the Mbum plateau? How is the nature of environmental degradation related to peasant out-migration from this plateau area? What are the main migration streams emanating from the plateau? How far can migration constitute a long lasting adaptation strategy to the environmental changes that have occurred in the Mbum plateau region?

\subsection{Spatial Context}

This paper covers the Mbum plateau and the plain of Mbaw. The Mbum plateau consisting of the Nkambe and Ndu districts is northernmost part of the more extensive Nkambe plateau. The Nkambe plateau is a basaltic highland which covers most of the present day North West Region of Cameroon. Its extent is limited by surrounding lower planation surfaces on basement rock cut down to different degrees of steepness like the Donga plain to the north; the Mbaw and Ndop plains to the east and south; and the Tubah and Kom mountain ranges to the west. Heights on this plateau range from $1400 \mathrm{~m}$ to over $3000 \mathrm{~m}$ asl and it is dominated by peaks like the Mounts Oku (3011m asl) and Njiseng (Binka) rising to over $2222 \mathrm{~m}$ asl. Average rainfall is about $2700 \mathrm{~mm}$ per annum and mostly falls from June to October because the climate of the area is marked by strong seasonality in which the rainy season runs from mid-march to November and the dry season from December to mid-March. November, April and May are intermediate months. A variety of rock types have made the soil patterns on the plateau complex because even over short distances, soils may differ considerably in such characteristics as texture and depth. These soils are however extensively used for subsistence farming of maize as a dominant crop in addition to others like groundnuts, irish potatoes, yams, beans, and coffee. (Awah., Kips., Kuoh \& Tchuenteu, 1987). The predominant vegetation on the plateau is savannah while remnants of natural forest occur on the windward sides of mountains in Kilum and Ijim (Oku), Kovifem (Mbiame), and Njiseng (Binka) and in plains and valleys like Mbembe and Mbaw.

Mbaw is a small part of the Tikar plain whose stretches are found in four regions of Cameroon: the North West, West, Adamawa and the Centre. The total area of the plain is about $75000 \mathrm{Km}^{2}$ and the population density is generally less than 4 persons per $\mathrm{Km}^{2}$ (Zapfack \& Ngobo, 1999). The Mbaw plain has an average density of 19 persons per $\mathrm{Km}^{2}$, far below that of the Mbum plateau with an average density of over 49 persons per $\mathrm{Km}^{2}$ (Population statistics compiled from BUCREP, 2010; Carpenter, 1933; and surface areas derived from Hof J et al, 1987)

Its climate is the Sudan tropical type characterised by a long rainy season and a short dry one. Average rainfall stands at about $1600 \mathrm{~mm}$ per annum and the annual mean temperature is $29^{\circ} \mathrm{C}$. The average altitude of the plain is about $700 \mathrm{~m}$ above sea level and its soils are tropical grey-red earths or ferruginous, being essentially derivatives of granitic deposits. There are equally volcanic soils of the basaltic type and depositional formations of alluviums and unsorted swamp soils.

The vegetation is dominantly the tree savannah type and remnants of forest are found along some river courses and wetlands. Figure 1 shows the location of the Mbaw plain amidst other farming frontiers in the North West region.

The Mbaw plain currently constitutes a highly sought after destination for farmers from the Mbum plateau whose gravelly soils (Awah., Kips., Kuoh \& Tchuenteu, 1986) have been degraded by several decades of permanent crop cultivation. In addition to soil degradation, population increase and conflict over limited fertile farmlands as triggers of migration, seasonal drought which tends to be severer on the plateau because it loses all its waters to neighbouring lowlands has caused the area to depend nearly exclusively on rain-fed agriculture. 


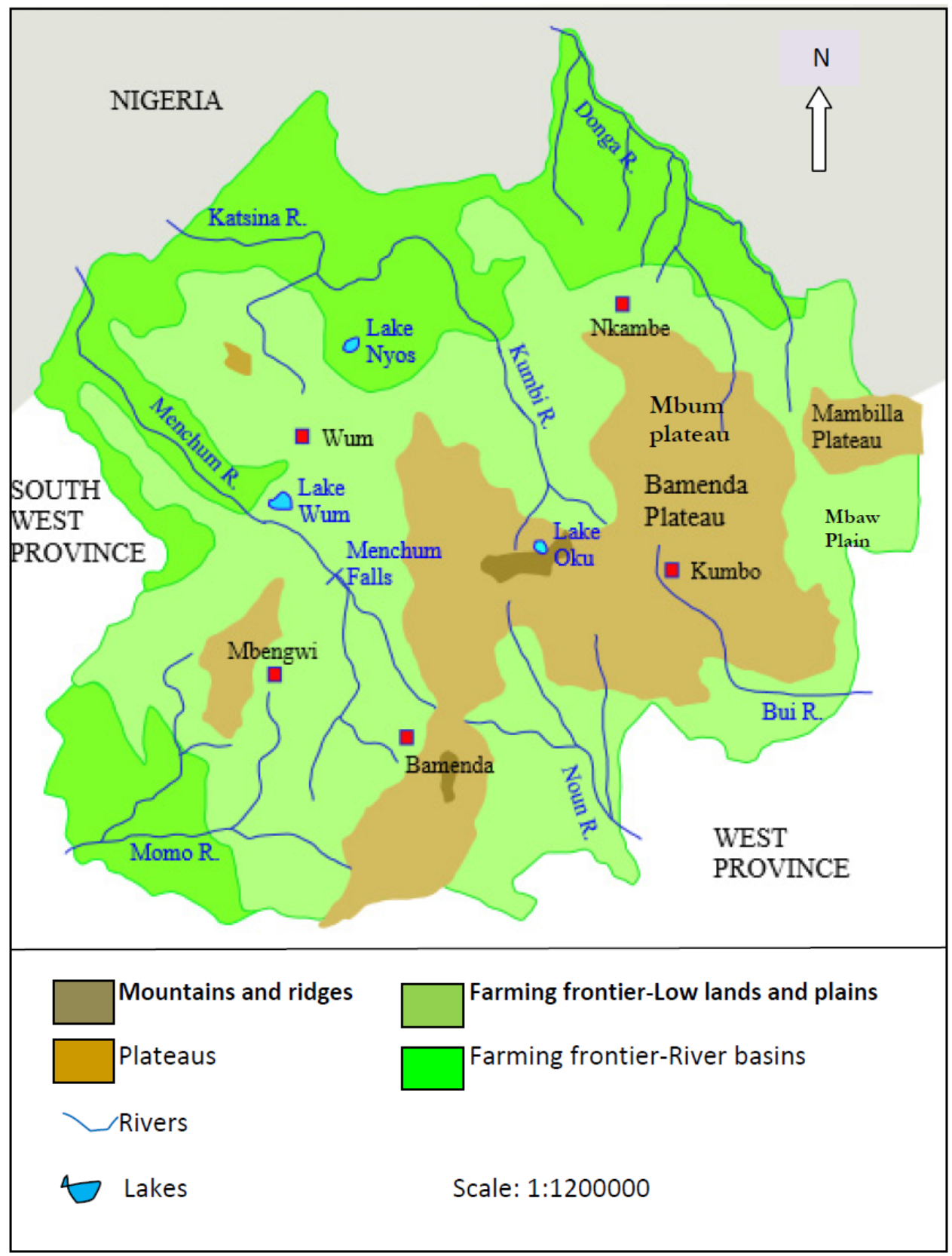

Figure 1. Farming frontiers in the North West Region

\section{Materials and Methods}

This study describes the implications of the bio-geographical changes which have occurred on the Mbum plateau on farming and resultant out-migration. To achieve this, both quantitative and qualitative techniques of research were employed. Environmental changes were evaluated from climate, vegetation, and empirical hydrologic and soil data. Climatic data was obtained from the meteorological station of the Cameroon Tea Estate in Ndu which produces the most reliable data in the Ndu-Nkambe area, while the topographic map extract of Nkambe (NB.32-VXII) of 1971 provided some data on past land cover and land use. Two series of Landsat images L7118056_05620070105 and p186r056_4dt19880202_z32 were used to do a supervised classification of the land use and land cover of the Mbum plateau in ERDAS. From the classification, land use and land cover statistics were obtained between the two dates. That permitted a comparative assessment of the environmental changes that have occurred in the area between 1988 and 2007. 
Few dissertations based on the Nkambe plateau provided invaluable information that helped to characterise the forms of environmental degradation in the study area. Questionnaires were used for surveys into the population's perceptions on environmental degradation and alternative courses of action open to peasant farmers. The following analyses were carried out on the data:

- the coefficient of variation of rainfall data was calculated since this element was considered the most important climatic input into peasant farming on the plateau;

- land use and land cover changes were evaluated from the analysis of Landsat images, personal communications and field observations;

- $\quad$ soil properties were ascertained under different land uses and land cover over reasonable periods of time to determine their effects on soil fertility;

- the questionnaire was analysed for peasant perceptions on environmental changes and their adaptation strategies both in and out of the plateau area.

These led to the characterisation of land degradation, migration, and the agricultural dynamics in the plain.

\section{Results}

\subsection{Variations in Climatic Elements}

Temperature and rainfall stand out as the most determinant climatic elements in agriculture globally. With the dominant crop of the Mbum plateau being maize, drought often characterised by the late onset of rains or the occasional occurrence of torrential downpours severely affects the crop. The analysis of the variation in average annual temperatures and rainfall recorded at the Cameroon Tea Estates in Ndu over a twenty-year period is presented in Tables 1 and 2.

Table 1. Average annual temperature of Ndu over a 20 year period

\begin{tabular}{cccc}
\hline Year & Temperature in ${ }^{\circ} C(X)$ & $X-X$ & $(X-X)^{2}$ \\
\hline 1989 & 16.65 & -0.42 & 0.1764 \\
1990 & 17.09 & 0.02 & 0.0004 \\
1991 & 16.99 & -0.08 & 0.0064 \\
1992 & 16.60 & -0.47 & 0.2209 \\
1993 & 16.07 & -1 & 1 \\
1994 & 17.11 & 0.04 & 0.0016 \\
1995 & 17.12 & 0.05 & 0.0025 \\
1996 & 16.89 & -0.18 & 0.0324 \\
1997 & 17.29 & 0.22 & 0.0484 \\
1998 & 17.64 & 0.57 & 0.3249 \\
1999 & 17.02 & -0.05 & 0.0025 \\
2000 & 17.05 & -0.02 & 0.0004 \\
2001 & 17.56 & 0.49 & 0.2401 \\
2002 & 17.34 & 0.27 & 0.0729 \\
2003 & 16.97 & -0.1 & 0.01 \\
2004 & 17.59 & 0.52 & 0.2704 \\
2005 & 17.55 & 0.48 & 0.2304 \\
2006 & 17.38 & 0.31 & 0.0961 \\
2007 & 17.27 & 0.2 & 0.04 \\
2008 & 17.22 & 0.15 & 0.0225 \\
& $X=341.36$ & & $2 . X-X)^{2}$ \\
& 17.07 & & 2.7992 \\
& $\sqrt{\Sigma}(\mathrm{x}-\mathrm{x})^{2} / \mathrm{n}$ & &
\end{tabular}




$$
\begin{gathered}
\mathrm{CV}=\frac{\text { Standard }}{\text { Mean }} \\
0.374 \div 17.07 \times 100=2.19 \%
\end{gathered}
$$

The calculated coefficient of variation of $2.19 \%$ is very small compared with the mean annual temperature. This is indicative of a minimal degree of dispersion. Over the years, temperature changes have not been as momentous as to significantly affect agricultural production on the plateau (see figure 2). Nonetheless, there has been a small but steady rise in average annual temperature on the plateau in the past twenty years.

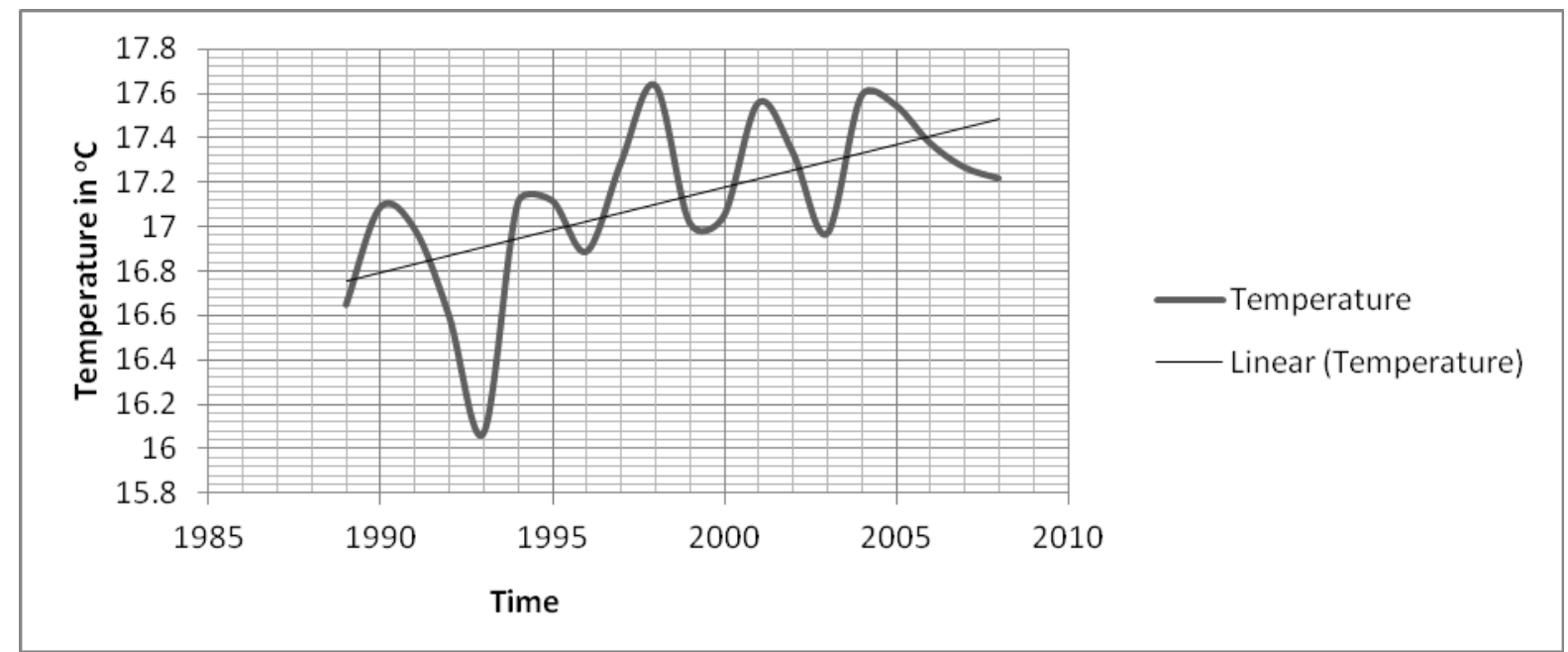

Figure 2. Temperature fluctuations over a 20 year period

Average annual rainfall analysis over the same period like temperature above resulted in a coefficient of variation of $10 \%$, a figure still largely lower than the mean annual rainfall, equally rejecting fluctuations in rainfall as a major cause of low agricultural production on the Mbum plateau. 
Table 2. Average annual rainfall of Ndu over a 20 year period

\begin{tabular}{cccc}
\hline Year & Rainfall $(\boldsymbol{X})$ & $\boldsymbol{X}-\boldsymbol{X}$ & $(\boldsymbol{X}-\boldsymbol{X})^{2}$ \\
\hline $\mathbf{1 9 8 9}$ & 1785.5 & -289.5 & 83810.25 \\
$\mathbf{1 9 9 0}$ & 2273.1 & 198.1 & 39243.61 \\
$\mathbf{1 9 9 1}$ & 2281.1 & 206.1 & 42477.21 \\
$\mathbf{1 9 9 2}$ & 2533.0 & 458 & 209764 \\
$\mathbf{1 9 9 3}$ & 1876.9 & -198.1 & 39243.61 \\
$\mathbf{1 9 9 4}$ & 2095.4 & 20.4 & 416.16 \\
$\mathbf{1 9 9 5}$ & 1938.6 & -136.4 & 18604.96 \\
$\mathbf{1 9 9 6}$ & 2074 & -1 & 1 \\
$\mathbf{1 9 9 7}$ & 1801.1 & -273.9 & 75021.21 \\
$\mathbf{1 9 9 8}$ & 2035.4 & -39.6 & 1568.16 \\
$\mathbf{1 9 9 9}$ & 2327.5 & 252.5 & 63756.25 \\
$\mathbf{2 0 0 0}$ & 2086.7 & 11.7 & 136.89 \\
$\mathbf{2 0 0 1}$ & 1895.4 & -179.6 & 32256.16 \\
$\mathbf{2 0 0 2}$ & 2071.8 & -3.2 & 10.24 \\
$\mathbf{2 0 0 3}$ & 2289.5 & 214.5 & 46010.25 \\
$\mathbf{2 0 0 4}$ & 1685.9 & -389.1 & 151398.81 \\
$\mathbf{2 0 0 5}$ & 2135.7 & 60.7 & 3684.49 \\
$\mathbf{2 0 0 6}$ & 1981.3 & -93.7 & 8779.69 \\
$\mathbf{2 0 0 7}$ & 2332.8 & 257.8 & 66460.84 \\
$\mathbf{2 0 0 8}$ & 2008.5 & -66.5 & 4422.25 \\
& $\Sigma \times=41509.2$ & & $\Sigma(X-X)^{2}$ \\
& 2075.46 & & 887066.3 \\
& $\sqrt{\mathbf{2 0}(x-x)^{2} / n}$ & &
\end{tabular}

$\mathrm{CV}=\mathrm{SD} \div$ Mean $\times 100 \%$

$887066.3 / 20$

$=\sqrt{ } 44353.32$

$210.60 / 2075 \times 100=10 \%$

Figure 3 depicts rainfall as a fluctuating phenomenon along a linear value slightly higher than $2000 \mathrm{~mm}$. Over the years, rainfall has remained very steady with just a minor steady decline.

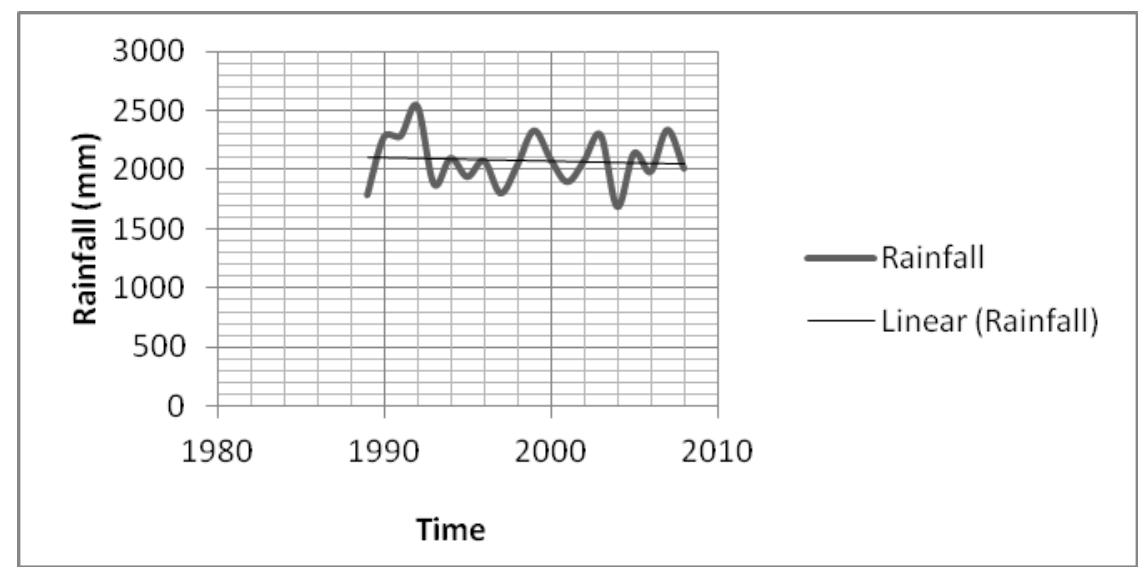

Figure 3. Trend in average annual rainfall over twenty years 
The foregone analysis of temperature and rainfall show that they have varied very minimally over the years to be the main drivers of out-migration from the Mbum plateau. Anthropogenic factors therefore seem to better explain environmental degradation in the area.

\subsection{Vegetation, water and soil changes}

Only few vestiges of natural forest still survive on the Mbum plateau. These are mainly sacred groves, montane and gallery forests. The existence of place names like Tukop, Mbukop, and Makop where kop means forest in limbum the language of the people of the Mbum plateau indicate an earlier existence of denser forest in the area. About $65 \%$ of the montane and gallery forests of the plateau have largely disappeared due predominantly to the colonisation of new land for arable and livestock farming. The present status of natural forest on the Mbum plateau is illustrated in Table 3.

Table 3. The evolution in the status of sacred or natural groves on the Mbum plateau

\begin{tabular}{|c|c|c|c|}
\hline $\begin{array}{l}\text { Locality (Quarter or } \\
\text { village) }\end{array}$ & $\begin{array}{l}\text { Number of sacred woods } \\
60 \text { years ago }\end{array}$ & $\begin{array}{l}\text { Current } \\
\text { number }\end{array}$ & Status of forest \\
\hline Njitop & 1 & 0 & $100 \%$ deforested \\
\hline Tukop & 1 & 0 & $100 \%$ deforestated \\
\hline Njipkfu & 2 & 2 & Reserve area \\
\hline Kuya & 2 & 0 & $100 \%$ deforested \\
\hline Lvu & 5 & 0 & $100 \%$ deforested \\
\hline Boyong & 1 & 0 & $100 \%$ deforested \\
\hline Ndu town & 3 & 0 & $100 \%$ deforested \\
\hline Nkambe town & 3 & 0 & $100 \%$ deforested \\
\hline Ngarum 1 & 8 & 0 & $100 \%$ deforested \\
\hline Ngarum 2 & 2 & 0 & $100 \%$ deforested \\
\hline Luh & 1 & 1 & Reserve area intact \\
\hline Nterbang (Wat) & 2 & 1 & Partially intact \\
\hline Nnwangri (Wat) & 4 & 4 & Forest reserve largely intact \\
\hline Mbandfung & 4 & 4 & Forest reserve largely intact \\
\hline Taku & 5 & 1 & Almost complete deforestation \\
\hline Mbah & 1 & 1 & Reserve intact \\
\hline Sambah & 2 & 2 & Considerably degraded \\
\hline Sehn & 5 & 2 & Marked reduction in size \\
\hline Ntumbaw & 3 & 0 & Complete deforestation \\
\hline Njila & 2 & 2 & Almost intact \\
\hline Njimnkang & 5 & 2 & Marked reduction in size \\
\hline Njiseng & 1 & 1 & Considerably degraded \\
\hline Total & 62 & 22 & $65 \%$ deforested \\
\hline
\end{tabular}

Amawa 1999, and complementary fieldwork, 2013.

The exotic eucalyptus has replaced the native trees of the Mbum plateau. The eucalyptus came to Cameroon in the late nineteenth century and possibly reached Donga Mantung Division in 1905 (Lukong, 2000). It is an evergreen plant and out of the 600 species known, two are commonly met on the plateau. These are the eucalyptus grandis and the eucalyptus saligna (Ngala 1992). Eucalyptuses require much water for growth and perform well in areas with average rainfall ranges of $1800 \mathrm{~mm}$ to $2450 \mathrm{~mm}$ in the wet season. Their roots can penetrate over three metres into the ground and extend laterally for over fifteen metres all in search of water. The water absorption ability of eucalypts, make them able to tolerate a wide range of pedologic and climatic regimes 
at the expense of most food crops.

Casson (1997) has noted the significant role of the eucalyptus in the depletion of ground water from different parts of the world. The hydrological implications have been felt generally on the Nkambe plateau but more especially on the Mbum plateau where eucalyptus plantations are most rampant. Field evidence indicates that eucalyptus in stream catchments contribute to lowering water tables and rendering some streams dry in the dry season. Many streams flowing from areas covered by eucalyptus are intermittent in flow, appearing in the rainy season and disappearing in the dry season. Table 4 illustrates the intermittent nature of first order streams in areas covered by eucalyptus in the study area.

Table 4. Number of intermittent first order streams in areas covered by eucalyptus

\begin{tabular}{llll}
\hline Locality & First order streams & First order streams covered by eucalyptus & Intermittent streams \\
\hline Mbarseh & 4 & 3 & 1 \\
Mbawngong & 3 & 3 & - \\
Nkambe & 6 & 5 & 1 \\
Ndu & 10 & 8 & 2 \\
Upper Mbot & 1 & 1 & - \\
Kuji & 3 & 0 & 3 \\
Wowo & 3 & 2 & 1 \\
Ngarum & 5 & 4 & 1 \\
Mbiyeh & 3 & 3 & - \\
Total & 38 & 29 & 09 \\
\hline
\end{tabular}

Amawa, 1999 and complementary fieldwork, 2013

The indiscriminate planting of the eucalyptus on the Mbum plateau is best illustrated in plate 1which show this tree growing in valleys and small depressions which often harbour streams.

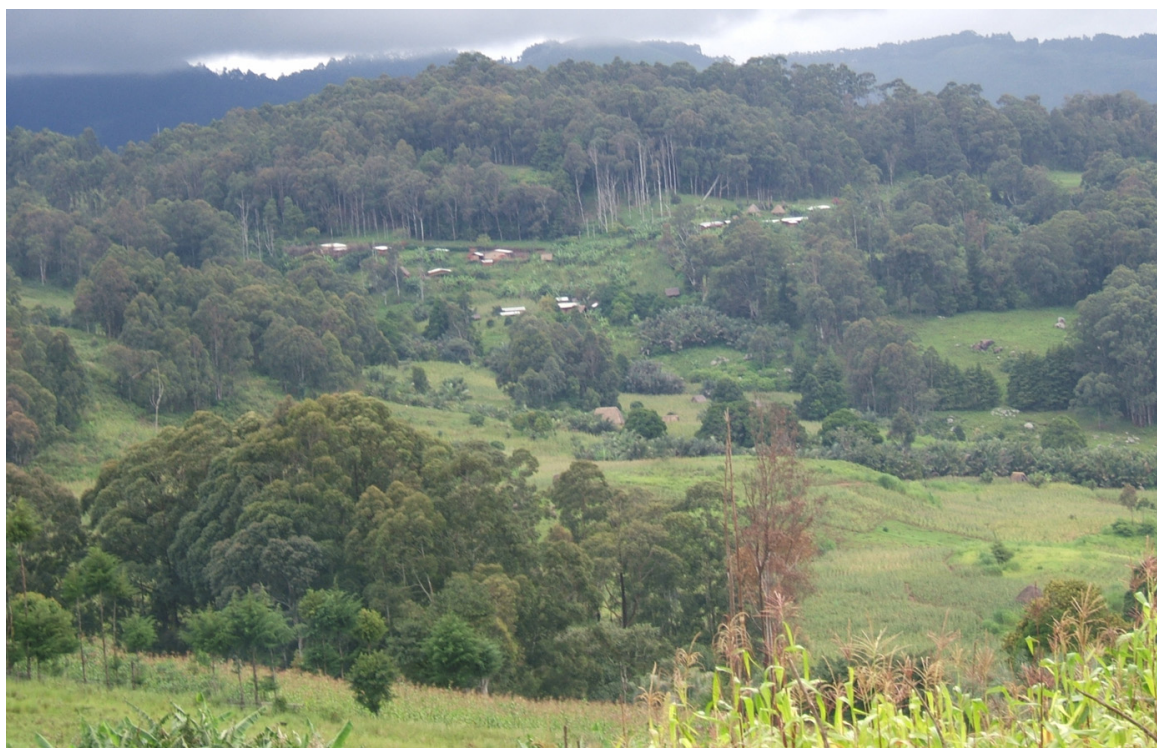

Plate 1. The dominance of the eucalyptus in the Ndu area

Source: Ntummang Mbunwe, 2011.

Surface drainage in the Nkambe municipality, the biggest town on the Nkambe plateau has progressively dwindled over the years (Ndi, 2009). Personal communications with the natives point to the fact that the volume of water issuing from the catchments has been on the decline. Streams from some catchments even cease to flow 
in the dry season. Dwindling groundwater is also felt by the Cameroon Water Utilities Company (CAMWATER), for there are occasional shortages of water from their supply system in the dry season. Their pumps work for longer periods in the dry than the rainy season although the number of hours during which water is pumped out daily has been increasing generally over the years. For example, from an average of 2.79 hours in 1992, the number of hours increased to over 7 hours in 2004 representing a $150 \%$ rise in the pumping rate over a period of 12 years. Similarly, the population of Nkambe grew from 13361 in 1987 to 17191 in 2005 representing a 28.6\% increase. Over a 17 year period, population increase was thus less than proportionate to the increase in the rate of water pumping. This indicates that population increase and the demand for water alone cannot explain the increased rate in groundwater extraction by CAMWATER in the Nkambe municipality. In the absence of strong climate variability on the plateau as seen earlier, land use practices are the most probable factors responsible for groundwater decline.

Table 5 shows that there has been a generalised negative evolution in the discharge of streams harnessed for water supply on the Mbum plateau over the thirty-year period considered in this study.

Table 5. Evolution in the discharge for water supply projects over time in different localities

\begin{tabular}{lllllll}
\hline Locality & $\begin{array}{l}\text { Year of first } \\
\text { measurement }\end{array}$ & $\begin{array}{l}\text { Discharge } \\
\mathrm{m}^{3} / \mathrm{hr}\end{array}$ & $\begin{array}{l}\text { in } \\
\text { Year of second } \\
\text { measurement }\end{array}$ & $\begin{array}{l}\text { Discharge } \\
\text { in } \mathrm{m}^{3} / \mathrm{hr}\end{array}$ & $\begin{array}{l}\text { Evolution } \\
\text { discharge (\%) }\end{array}$ \\
\hline Nkambe & 1966 & 14.5 & 1997 & 1.0 & -93.10 \\
CAMWATER & & & & & \\
(Nkambe) & 1986 & 30.0 & 1998 & 5.0 & -83.33 \\
Mbipgo & 1971 & 3.2 & 1997 & 1.08 & -68.75 \\
Ntumbaw & 1971 & 18.0 & 1997 & 1.2 & -93.33 \\
Ntundip & 1973 & 1.3 & 1997 & 0.5 & -61.51 \\
Mbarseh & 1972 & 1.3 & 1996 & 1.8 & +38.46 \\
Jirt & 1971 & 1.28 & 1998 & 1.26 & -1.5 \\
Taku & 1974 & 3.0 & 1997 & 2.8 & -6.6 \\
Kihfe & 1972 & 1.47 & 1997 & 1.47 & 0 \\
Sehn & 1975 & 2.9 & 1997 & 2.88 & -0.68 \\
\hline
\end{tabular}

CAMWATER, Nkambe, 1999 and Amawa, 1998.

Under the influence of both eucalyptus and poor farming techniques, soils have become generally impoverished. Eucalyptuses extract lots of nutrients from groundwater while bush burning accelerates the rate of soil erosion and nutrient loss. The North West region comes second to the Adamawa in nomadic livestock farming and the dominant pasture regeneration technique is bush burning in the dry season, a major factor in soil erosion. Soil properties measured under natural forest, eucalyptus forest at different ages and farmland on the Mbum plateau produced graphical illustrations of the relationships between these land uses and the evolution of soil moisture, nutrients, $\mathrm{pH}$ and other properties. The graphs reveal discernible patterns in the relationship between various soil properties and different land uses. These properties are higher in soils under natural forest cover and farmlands; decline under eucalyptus up to the age of 25 years, but tend to rise in eucalyptus plantations which are 30 years old definitely because of less nutrient intake at old age. Unfortunately, land under mature eucalyptus stands is not available for farming as lumbering of this tree has also become profitable. Eucalyptuses have been found to be strongly associated with variations in the concentration of soil fertility components and nutrients. Soils under various land uses were analysed for the concentration of the main soil fertility indicators as figure 4 shows. 

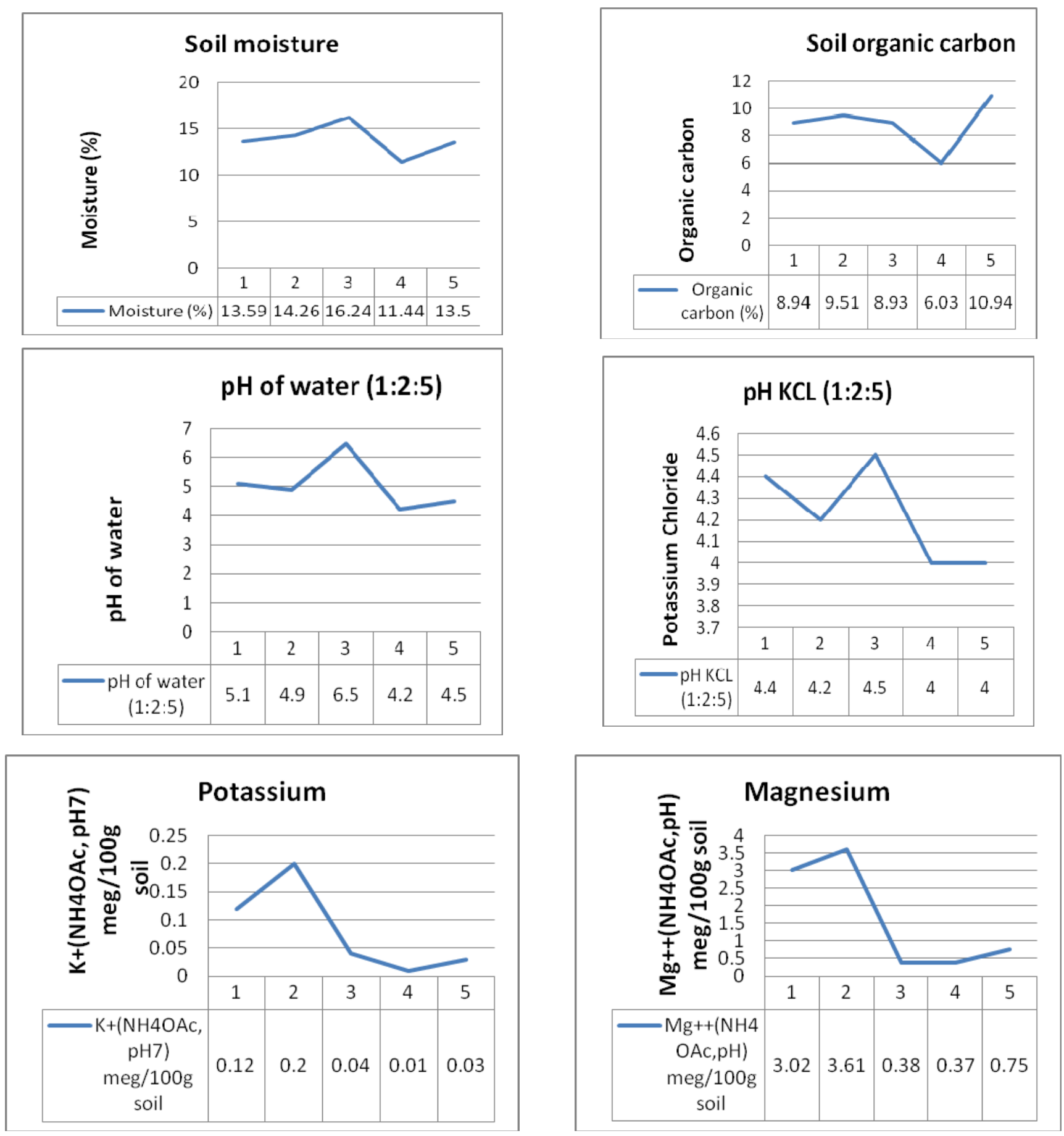

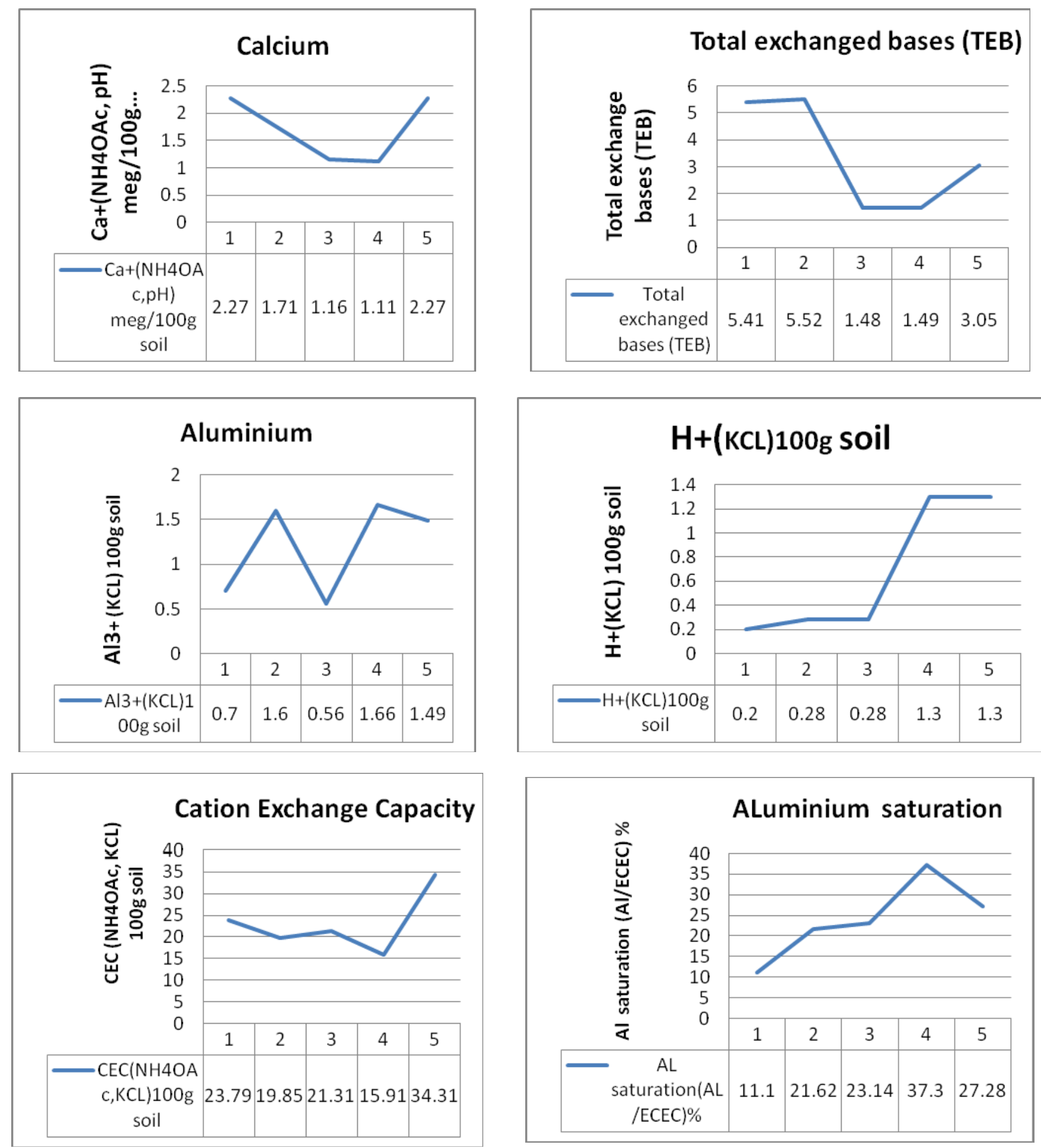

Figure 4. The effect of eucalyptus on soil fertility components on the Mbum plateau

Source: Adapted from Amawa (1999) Land degradation on the Mbum Plateau. Soil samples analysed at the Institute of Agricultural Research for Development, Ekona. Ref. No. 199.

From the analysis in figure 3, the concentration of soil moisture, organic matter, $\mathrm{pH}$ and cations showed wide variations from one land use type to another. Generally, soil moisture, organic matter and $\mathrm{pH}$ are lower in soils under eucalyptus plantations of about 25 years of age, than under natural vegetation and cropland and eucalyptus stands older than 30years. This corroborates the views of Casson (1997) and Ngala (1992) that eucalypts are 
very efficient groundwater users. The low concentration of organic matter and low $\mathrm{pH}$ in areas under this tree can be explained by the high concentration of hydrogen ions $(\mathrm{H}+)$ in soils in which it grows. A high concentration of $\mathrm{H}+$ often corresponds to a low $\mathrm{pH}$ value and vice versa. A low soil $\mathrm{pH}$ is capable of impeding the cation exchange capacity of the soil (CEC) by altering the surface charge of colloids (finest clay particles and soil organic matter) (McCauley, Jones \& Jacobsen, (2005). That is why the CEC in soils under eucalyptus on the Mbum plateau is lowest since the decomposition of organic matter is impeded by the existing low soil $\mathrm{pH}$. There is a tremendously low concentration of macro plant nutrients like potassium $(\mathrm{K})$, magnesium $(\mathrm{Mg})$, and calcium (Ca) in soils covered by eucalyptus stands because they are easily dissolved and removed to the lower horizons by hydrogen ions and chelating agents. These have equally rendered the soils under eucalypts generally impoverished and infertile for crops like maize, beans, and potatoes which need these bases and are the dominant crops on the plateau.

\section{Emergence of Agricultural Frontiers}

The generalised impoverishment of soils on the Mbum plateau has had two major consequences on the margins and character of crop cultivation on the plateau and in its lowlands:

- the colonisation of new lands away from eucalyptus plantations often on lofty slopes; and

- a steady movement by farmers from the plateau to source out new farmlands in the adjacent lowlands notably the Mbaw plain and Donga Valley (Mbembe lowlands).

\subsection{The Colonisation of New Land for Farming on the Plateau}

The colonisation of new farmlands further afield from settlements has increased steadily on the Nkambe plateau. Because of its hilly nature, lofty hills have come under increasing cultivation virtually everywhere. This has been facilitated by the existing low population densities in the area. For example, Ndu Sub Division on the Mbum plateau has a population density of 45 inhabitants per $\mathrm{Km}^{2}$, far below the regional density of 100 inhabitants per $\mathrm{Km}^{2}$. There is still much vacant land though the major constraint is low soil fertility, high gravel content and high aluminium saturation (Awah., Kips., Kuoh \& Tchuenteu., 1987). Being dominantly a peasant population, the main way to expand production is to push out the margins of cultivation. On the plateau, the farming margins have been pushed into the more fertile valleys and wetlands for the land owning peasants and in extreme cases, on to lofty hills for the poorer peasants. Figure 5 illustrates the evolution of land use and land cover types on the Mbum plateau from 1988 to 2007.

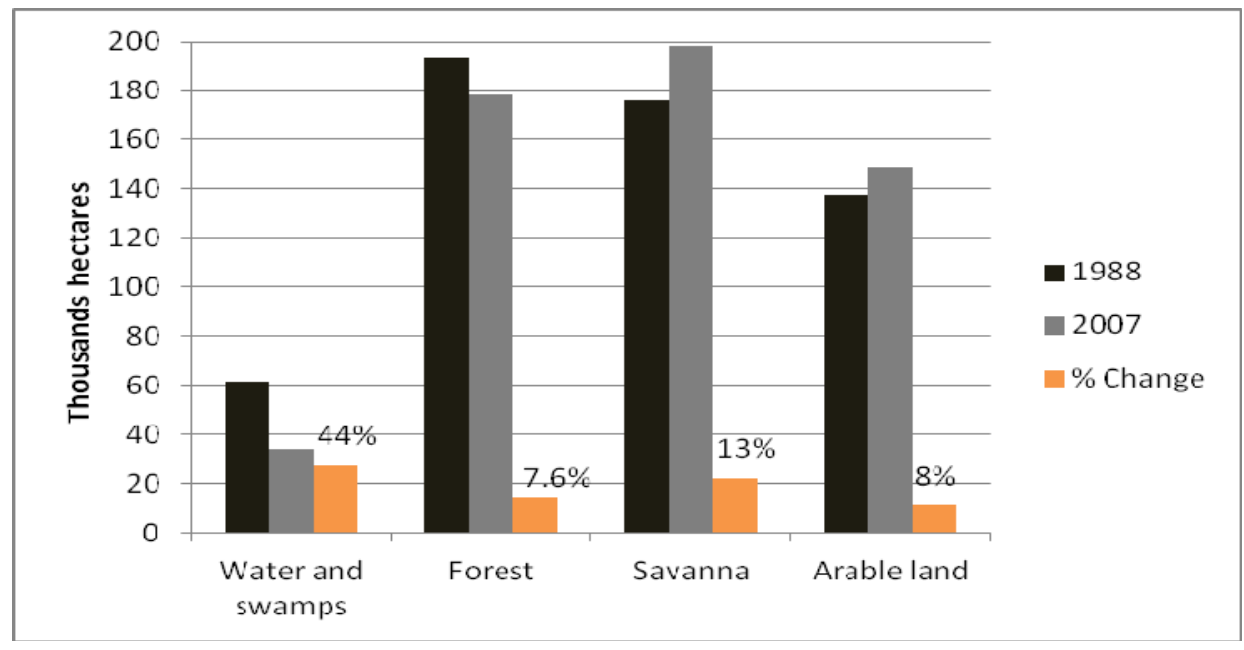

Figure 5. The evolution of land cover and land use on the Mbum plateau

Source: Statistics generated from land use and land cover classification using Landsat images of 1988 and 2007.

Water bodies and swamps, and forest have retreated within the period covered by the images processed by values of $44 \%$, and $7.6 \%$ respectively in favour of new farmlands. The rampant planting of the eucalyptus, in catchments may also explain the decline in water bodies and swamps. The increase in savanna of $13 \%$ may be explained by deforestation which has occurred by over $8 \%$. Arable and pastoral lands have also eaten into swamps and forest areas. This is spectacular in the valleys which are often transformed into conflict spots between arable and pastoral farmers. 


\subsection{Movements to Lowlands in Search of Fertile Land and Agricultural Diversification}

Altitudes on the Mbum plateau range from $300 \mathrm{~m}$ to $2200 \mathrm{~m}$ above sea level. The lowlands cover the Mbaw plain, the Donga valley; and the Misaje-Dumbo area. The agricultural population of the Mbaw plain is largely in-migrant. Of the 92 farmers interviewed at random in Mborong, Nwanti, Sabongari and Ntem all in the Mbaw plain in August 2011, $31 \%$ were natives; 51\% had moved in from various villages in the Ndu Sub-Division; 9\% from Nkambe Sub-Division; 4\% from Nwa Sub-Division and the remaining 5\% from Bui, Mezam and localities in the West Region of the country (Fig. 6).

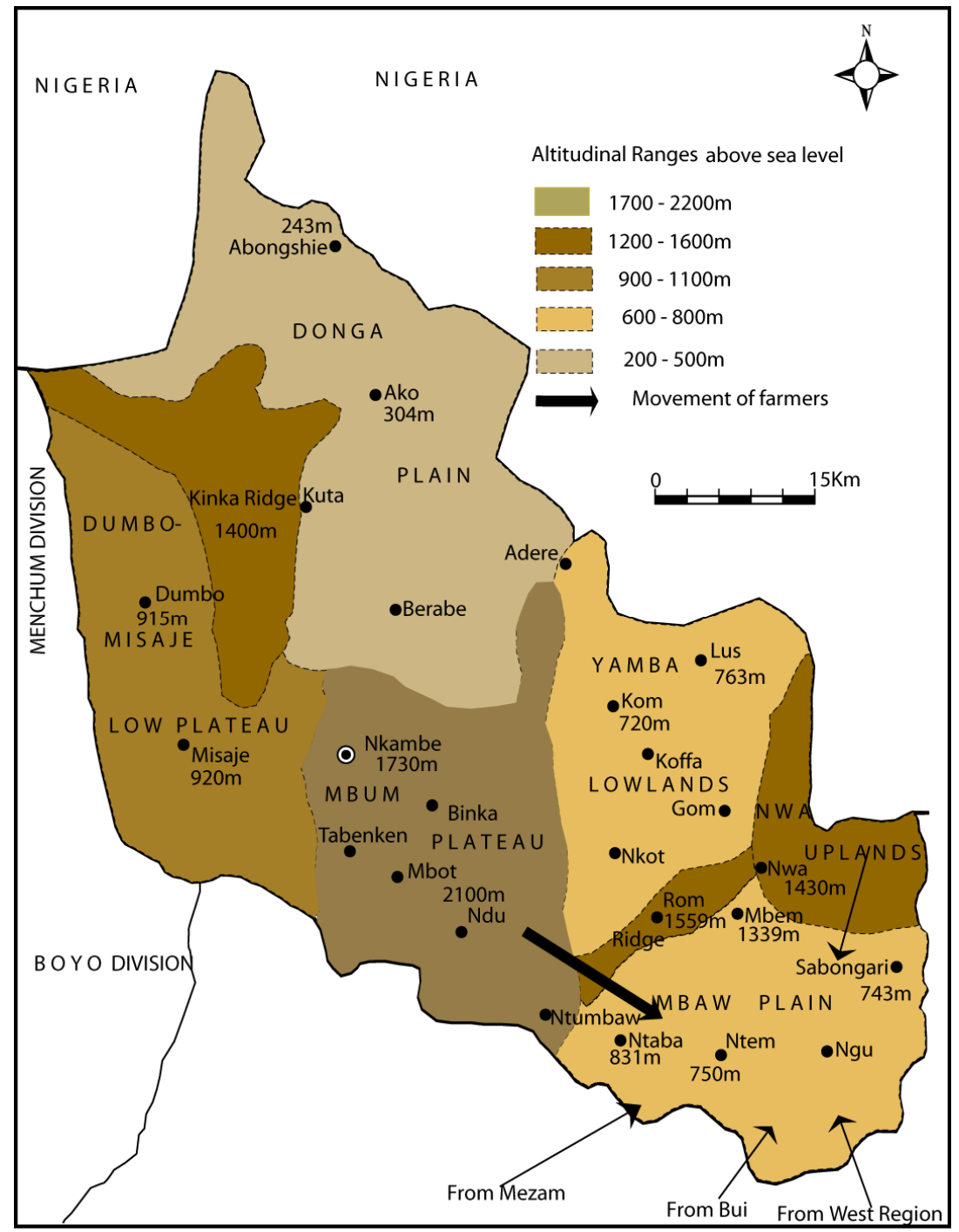

Figure 6. Farming movements into the Mbaw plain

Sixty-six percent of farmers interviewed agreed that they moved into Mbaw because of the availability of cheap and fertile farmland. Land degradation, desertification and deforestation are factors that potentially result in mobility as a household adaptation strategy because ecosystem degradation undermines the resiliency of farmers (Care et al., 2009). As opposed to the uplands of Ndu and Nkambe, the Mbaw plain tolerates a wider range of crops such as oil palms, rice, soya beans, maize, groundnuts, cocoa, coffee, cassava, ginger, egusi and beans amongst others. The farming pattern has a short history and is characterised by an increasing number of agro-industrial concerns.

By far a wider range of crops is grown in the Mbaw plain than its surrounding uplands. Mbaw is hot, humid, and has deeper soils richer in organic matter than the upland area. The range of crops grown is shown in Table 7. 
Table 6. The diversity of crops grown in the Mbaw plain

\begin{tabular}{ll}
\hline Type of crop & Growers (\%) \\
\hline Yam & 1 \\
Oil palm & 53 \\
Rice & 57 \\
Soya beans & 35 \\
Maize & 80 \\
Groundnuts & 43 \\
Cocoa & 40 \\
Coffee & 15 \\
Egusi & 5 \\
Cassava & 20 \\
Beans & 13 \\
Vegetables & 5 \\
Ginger & 5 \\
Others & 42 \\
\hline Souce: &
\end{tabular}

Source: Field work, August 2011.

Most of the migrant farmers interviewed indicated that they had been farming in Mbaw for about 20 years, and maintain close ties with their villages of origin. A few of the farmers, however, live permanently out of the plain but have employed labourers to live and work on their farms. This is notably the case of those cultivating oil palms and cocoa. These crops are grown on extensive scales for commercial purposes.

Although the Mbaw plain possesses the natural potential for oil palm cultivation, their prospects seem to be highest now because major private and parastatal stakeholders have become involved since the 1990s. For example, individuals now own plantations whose sizes range from 2 to 23 hectares. The rehabilitation of the Kakar - Sabongari - Sonkolong road that traverses the plain from Ntaba to Sonkolong in the Adamawa plateau gave it a major agricultural boast. There has been a remarkable increase in the number and types of plantations in the area. Amongst the various plantations are banana, cocoa, and oil palm plantations. Agricultural produce from the plain is sold in nearby collection markets of Ndu and Kumbo from where the bigger urban markets are supplied.

\section{Discussion and conclusion}

Environmental change was a permanent hallmark of the last century and in spite of the increasing awareness of the eminent human vulnerabilities to environmental threats, the trend has remained high. Because of their weak adaptive capacities, developing countries tend to be more vulnerable to environmental changes such as climate changes than the developed countries. It is estimated that there will be a 5-8\% increase in arid land in developing countries by 2080 (Schmidtt, 2009). In agricultural communities, the poorest groups or peasants who depend entirely on rain fed agriculture are most exposed to environmental changes. Adverse environmental changes inevitably orchestrate livelihood saving actions including movement away from the adversity.

Even though the scientific link between environmental change and migration has been difficult to set, many inferences as to the existence of such links can be made from national and regional migratory trends. Renaud et al (2007) citing Desertif' Actions (2006) have noted that the cause-effect relationship between a phenomenon like desertification and migration has been flagged by different conferences and stakeholders. Land degradation renders livelihoods precarious, causing poverty to become entrenched because people become marginalised thus orchestrating or enforcing economic losses and migratory flows. Studies in the Malian region of Kayes reveal that two out of three families have a member of their household overseas notably in the coastal countries of West Africa. Whereas, movements into the Mbaw plain are becoming important in magnitude, few of them are permanent. They can best be classified under circular movements because farmers move from their native areas to the new farming frontiers only seasonally. Care et al., (2009) have observed that seasonal migration plays an important part in the struggles of many families to deal with environmental change. This entails moving from 
one rural area to another in search of ecosystems that can still support livelihoods. With the current fast pace colonisation of land in the Mbaw plain; the project to develop small holder oil palm production schemes by the Cameroon Development Corporation; and the emergence of private oil palm plantations, land speculation has increased. Circular movements are thus likely to reduce in favour of permanent ones in the near future if circulating peasants have to secure their rights to the land.

Movement under environmental stress is a common feature of the rural milieus in the tropics. Movement constitutes an acceptable coping strategy for peasant farmers of the Mbum plateau in the short term, but increasing and uncontrolled movements into farming frontiers may soon jeopardise their ecosystems and initiate land use conflicts. As a result of speculation, land related conflicts are already springing up in the Mbaw plain. For example, conflicts over farmlands have been recorded between the following villages: Ntem versus Nwanti and Ntumbaw versus Njirong. In addition to these, environmental degradation and the decline of ecosystem services is accelerating. It is probable that the environmental, economic, social and cultural dynamics that produced stress and generated out-migration from the Mbum plateau are being replicated in the plain. The question arises as to where the population will migrate to when the Mbaw plain has sufficiently been stressed as to generate new waves of environmental out-migration. This puts to question the practice of migration as a peasant adaptation strategy. Adopting land use planning policies to reduce arbitrary land sales and occupation may not succeed because of the existing customary claims to land. It seems that only an evolution of the agricultural system from the subsistence to the modern will eventually deter peasants from moving.

\section{References}

Amawa, S. G. (1999). Land degradation on the Mbum plateau (North West Province of Cameroon). Unpublished M.Sc. thesis, Department of Geography, University of Buea.

Awah, E. T., Kips, P. H, Kuoh, M. H., \& Tchuenteu, F. (1987). A clino-sequence of red and brown soils on basalt in the Nkambe area, north west Cameroon: characterisation, classification and agricultural implications. Proceedings of the Regional Seminar on Lateritic soils, material and minerals, 21-27 January 1986, Douala, Cameroon. ORSTOM. pp. 173-185.

Bancour, P. (2008). Climate change, migration and forced displacement: the new humanitarian frontier? 14th Conference of the Parties to UNFCCC Side Event UNHCR in association with IOM and UNU.

BUCREP. (2010). Rapport de presentation des resultat définitifs, BUCREP.

CARE., CIESIN., UNHCR., UNU-EHS., \& World Bank (2009). In search of shelter: Mapping the effects of climate change on human migration and displacement.

Carpenter, F. W. (1933). An intelligence report on the Mbaw, Mbem and Mfumte areas, hitherto jointly known, as, the Kaka-Ntem area of the Bamenda Division of the Cameroon Province. Buea Archives File № Ac. 5. Original File № 1461.

Casson, A. (1997). The controversy surrounding eucalyptus in social Forestry programmes of Asia.

The Australian National University. Australia.

Graßi, H., Schubert, R., Epiney, A., Kulessa, M., Luther, J., Nuscheler, F., Sauerborn, R., Schellnhuber, H. J., \& Schulze, E. D. (2004). World in Transition: Fighting poverty through environmental policy. London and sterling, VA, Earthscan.

Gregory, D., Johnston, R., Pratt, G., Watts, M., \& Whatmore, S. (Eds.). (2009). The dictionary of human geography. Blackwell Publishing Ltd.

Hof, J., Numbem, S. T., Ndjib, G., \& Griesback, J. C. (1987). Soil, land use and land evaluation of the North West Province of Cameroon. Ministry of Higher Education and Scientific Research; Ministry of Agriculture; MIDENO \& IRA.

International Organisation for Migration. (2009). Migration, climate change and the environment. IOM Policy Brief, Geneva.

Johnston, R. J., Gregory, D., \& Smith, D. M. (Eds.). (1994). The dictionary of human geography. Oxford and Massachusetts, Blackwell Publishers Ltd.

Lukong, J. J. (2000). Cultivation of eucalyptus: its socio-economic significance and environmental implication in Vekovi. (Unpublished Term Paper), Higher Teacher Training College Annexe Bambili, University of Yaounde 1. http://dx.doi.org/10.1126/science.333.6042.544

Malakoff, D. (2011). Are more people necessarily a problem? Science, 333, 544-546. 
McCauley, A., Jones, C., \& Jacobsen, J. (2005). Basic soil properties: soil and water management module I. Montana State University Extension Service. Retrieved March 4, 2014, from http://landresources.montana.edu/SWM/PDF/Final_proof_SW1.pdf

Ndi, H. N. (2009). Economic and political conflicts in potable water catchment management in Nkambe Town, North West Region of Cameroon. In Conflict Prevention, Management and Resolution. II PGS Buea.

Newbold, K. B. (2010). Population geography: Tools and Issues. Rowman and Littlefield Publishers, INC.

Ngala, P. T. (1992). Afforestation: the growth and exploitation of eucalyptus in Nkambe subdivision. (Unpublished DIPES II thesis), Higher Teacher Training College Yaounde, University of Yaounde.

Ngane, E. B., Ngane, B. K., Ndjib, G., Awah, E. T., \& Ehabe, E. E. (2012). Land consumption and related degradation patterns by major agricultural uses in the humid tropical savannah of North West Cameroon. Agricultural Science Journal, 2(6), 318-323.

Ntummang, M. (2011). Land use change in Ndu Sub-Division, North West Region of Cameroon. (Unpublished Masters Dissertation), University of Douala.

Oliver-Smith, A., \& Shen, X. (2009). Linking environmental change, migration and social vulnerability. SOURCE № 12/2009, UNU-EHS \& Munich Re Foundation.

Renaud, F., Bogardi, J. J., Dun, O., \& Warner, K. (2007). Control, adapt or flee: How to face environmental migration? InterSecTions $\mathrm{N}^{\mathrm{o}} 5 / 2007$, Publication series of UNU-EHS.

Rogers, P. P., Jalal, K. F., \& Boyd, J. A. (2008). An Introduction to sustainable Development. London, Earthscan.

Sarukhan, J., \& Whyte, A. (2005). Millennium Ecosystem Assessment, 2005. Ecosystems and Human Wellbeing: Synthesis. World Resources Institute, Washington.

Schmitt, W. (2009). Climate change adaptation and development: what is at stake? Keynote address, IHDP Openmeeting, Bonn.

Schubert, R., Scellnhuber, H. J., Buchmann, N., Epiney, A., Grießhammer, R., Kulessa, M., Messner, D., Rahmstorf, S., \& Schmid, J. (2008). Climate Change as a security Risk. London and Sterling VA, Earthscan.

UN. (1992). United Nations Framework Convention on Climate Change, New York. Retrieved April 16, 2013 , from http://www.unccd.int/Lists/SiteDocumentLibrary/conventionText/conv-eng.pdf

UN. (1994). United Nations Convention to Combat Desertification in Countries Experiencing Serious Drought and/or Desertification, particularly in Africar $\quad$ Retrieved from http://www.unccd.int/Lists/SiteDocumentLibrary/conventionText/conv-eng.pdf.

UNU-IHDP-UNEP. (2012). Inclusive Wealth Report 2012: Measuring Progress towards Sustainability. Cambridge University Press.

Vollmer, R., \& Fischer, C. (Eds.). (2009). Brief 39: Migration and displacement in sub Saharan Africa. The security-migration nexus II, Bonn, BICC, pp. 29-37.

Weeks, J. R. (2008). Population: An introduction to concepts and issues. Thomson Wadsworth.

World Bank. (2013). Africa's Pulse: an analysis of issues shaping Africa's economic future, vol. 8, World Bank.

Zapfack, L., \& Ngobo, N. M. (1999). A participatory survey and inventory of timber and non timber forest products of the Tikar plain a report for IR1/CARPE.

\section{Copyrights}

Copyright for this article is retained by the author(s), with first publication rights granted to the journal.

This is an open-access article distributed under the terms and conditions of the Creative Commons Attribution license (http://creativecommons.org/licenses/by/3.0/). 